\title{
A blank piece of paper
}

\section{Ian Yeoman ${ }^{1}$}

Published online: 28 May 2020

(c) Springer Nature Limited 2020

Revenue Management in the face of COVID-19 is a blank piece of the paper.

Publisher's Note Springer Nature remains neutral with regard to jurisdictional claims in published maps and institutional affiliations.

Ian Yeoman

ian.yeoman@vuw.ac.nz

1 Victoria University of Wellington, Wellington, New Zealand 